which these experiments were published. Some of the technical detail is obscure, in part because instruments or components are referred to by alphanumerical designations which have no clear meaning in English. The English of the translation is not as clear as that of the review and the ground which is fully covered in the book is little greater than that of the review, nor is it appreciably more up to date.

It is disappointing not to bo able to recommend this book. It certainly contains more of Ugolev's work than has yet been published in English, but it is not likely to be of value to anyone not engaged in work in closely related fields.

R. B. FISHER

\section{PLAGUE ON THE FARMS}

The Great Cattle Plague

An Account of the Foot-and-Mouth Epidemic of 1967-8. By Ralph Whitlock. Pp. $111+12$ plates. (Baker: London, 1968.) $25 s$.

THe great cattle plague Ralph Whitlock describos is, of course, the foot and mouth disease opidemic of the winter of 1967-8 which bocame the greatest disaster British animal husbandry has ever suffered; between October 25, 1967, and the end of February 1968 over two hundred thousand cattle and over four hundred thousand sheep and pigs were slaughtered. Estimates of the total cost of the epidemic exceed $£ 100$ million.

Whitlock, who is the farming correspondent of The Field, and a farmer, was obviously quick to realize that in the appalling events which he saw and reported he had the makings of a book. He has written a fascinating, albeit lugubrious piece of extended journalism with enough editorial slips to attest the rush to the press. In seven short chapters centred on a week by week account of the plague months, he successfully conveys something of the feelings of the farming community-its anger, depression and above all impotence-during the epidemic, and the arguments that still continue over what might have been done or should bo done in the future. Inevitably, the book is unfinished; the final chapter can only be written when the Duke of Northumberland's Committce of Inquiry produces its reports and reveals what has been learnt from this bitter lesson.

The first three chapters are devoted to the history of the disease in Britain since the first recognized case in 1839 , the nature of the virus and the disease, and the mechanics of the British slaughter policy. Naturally, Whitlock is more at home with foot and mouth disease on the farm than in the laboratory, and his journalistic style leads to statements such as "It [the virus] thrives on cold and darkness". But, all in all, the background introduction manages creditably enough to set the scene, contrasting the successes in Victorian times of a slaughter policy against rinderpest and pleuropneumonia with the failure of the slaughter policy against foot and mouth disease. Whitlock oven reaches the conclusion at the end of his first chapter that, "from the statisties it could be argued that foot and mouth discaso has been winning", but like most farmers he maintains throughout that slaughter is the best and only policy.

There is no comment on one of the most curious circumstances of the epidemic; namely, that on the day that the first case was confirmed, animals from the infected farm were being sold at a nearby market with some 7,000 head of livestock. But Whitlock describes the criticism of the Ministry of Agriculturo which mounted as the magnitude of the outbreak became clear. Farmers were particularly angered by the apparently inconsistent, way in which the ministry cancelled public events, and by the ministry's contradictory advice on disinfectants. More scriously, the ministry apparently refused to consider a preparation specifically made to kill foot and mouth diseaso virus by a Manchester company on the grounds that it did not fit into any of the categories listed in an Act of Parliament of 1932. And yet the deputy director of the Animal Virus Research Institute at Pirbright said, "This is the fastest acting disinfectant we have tested for reaction against foot and mouth disease virus".

Whitlock is at his best describing the reactions of individual farmers to the desolation of assisting in the destruction of generations of work and the loss of tens of thousands of pounds worth of stock. And his descriptions bear out another criticism of the ministry-the delays in the disposing of the slaughtered animals. One farmer, for example, had his stock of 120 cows slaughtered on a Saturday evening, but not until the following Wednesday had 250 railway sleepers, 450 bales of hay, three lorry loads of old tyres and 200 gallons of oil been collected for the pyre. So for three days the 120 carcasses lay rotting as a source of further infection. The Gowers Report in 1954 said that the chief reason for preferring cremation to burial "was that carcassos should be disposed of as quickly as possible". It is incredible that in a national emergency the Ministry of Agriculture cannot find more portable bonfire materials than old tyres and railway sleepers-it should consult its friends in the Ministry of Defence. Whitlock is least convincing when he comes to discuss the alternatives to slaughter. Out come all the old arguments against vaccination, which he claims would lead to endemic foot and mouth disease. And he has not done his homework about the cost of vaccination. He is content to repeat the estimate of $£ 20$ million a year published in the Gowers Committee report, adding for good measure that it might cost as much as $£ 100$ million annually. Experience in France and the development of cheaper and polyvalent vaccines since 1954 are not mentioned. But apart from the one-sided discussion of vaccination, the book is a balanced and readable account of the 1967-8 epidemic and the problems an outbreak of foot and mouth disease poses. JOHN TOOZE

\section{PLASTIC MOULDING}

Injection Mould Design (for Thermoplastics)

By R. G. W. Pye. Pp. $8+417$. (Iliffe: London, December 1968. Published for the Plastics Institute.) $115 s$.

INJECTION moulding, which consists of forcing heated plastic material at high pressure into a metal mould through a constricted orifice, is probably the most effective method for production of large numbers of articles of all kinds. When the method was first introduced it was applied to the moulding of objects of comparatively simple shape permitting easy withdrawal of the product when two halves of the mould were separated. With the passing of the years, much ingenuity has been devoted to devising means for the production of components the shapes of which have become increasingly complicated.

The major requirements of mould design are the provision of means, (1) to secure correct alignment of the various components which determine the shape of the product, (2) to enable the finished component to be automatically ejected from the mould, (3) to secure the plastic flow of the material into the most remote and inaccessible parts of the moulding, (4) to cool the mould and the product, and (5) to permit the escape of air displaced by the plastic material. The book describes, in full detail, the various solutions which have been adopted to meet these requirements and is exceptionally well illustrated, every description being accompanied by clear black-andwhite diagrams.

The subject is treated in two parts. The first part deals with the more straightforward cases of mould making, mould construction, ejection systems and their 